\title{
DIFFERENT LOAN SOURCES AS A REASON FOR VARIABILITY IN SOME ESTONIAN DIALECT WORDS
}

\author{
Iris Metsmägi, Meeli Sedrik and Vilja Oja \\ Institute of the Estonian Language
}

\begin{abstract}
Among other reasons, the phonetic variability of loanwords in Estonian dialects may reflect their origination from different but etymologically connected sources of borrowing. In an etymological dictionary, it is essential to find the words originating from different loan sources. In the present article, some dialect words and their variants are analysed from this aspect. Sometimes the different loan sources have concrete criteria, e.g. variants with different stem vowels in the words kann 'jug', nunn 'nun', and kirn 'churn', while some cases are not as clear, e.g. kartul and tuhl(is) 'potato', kapsas and kaapsas 'cabbage', and reetkamm and reigam(m) 'reed'. If certain phonetic criteria are lacking, the areal distribution of variants may give valuable information about the possible loan sources. The analysis of a group of etymologically connected loanwords for 'shuttle', together with their further developments in Estonian dialects, illustrates the complexity of lexical relations in Estonian dialects.
\end{abstract}

Keywords: Estonian dialects, stem variability, Low German loanwords, German loanwords, Swedish loanwords, Estonian-Swedish loanwords, Russian loanwords, Latvian loanwords

DOI: http://dx.doi.org/10.12697/jeful.2014.5.2.03

\section{Introduction}

Etymologists are aware of the fact that especially younger loanwords are often characterized by a multitude of variants in Estonian. Some variants can be considered as regular or at least predictable, as they reflect regular phonetic changes of certain dialects characteristic to the whole vocabulary (e.g. the diphthongization of some long vowels in northern Estonian dialects), or typical variability in the adaptation of loanwords in Estonian (e.g. the parallel variants with or without first syllable, corresponding to the unstressed first syllable of the loan source). However, there are plenty of variants that cannot be explained in this way. 
At the same time, there are many loanwords in Estonian that are borrowed in parallel from different contact languages. This concerns the etymological equivalents of a stem in mutually related contact languages (e.g., in Low German, German and Swedish), as well as words borrowed by contact languages from each other or from the same donor language. Sometimes the different sources of such parallel borrowings are quite obvious in terms of phonetic or semantic criteria but sometimes the situation is unclear.

Thus, in the case of variants which cannot be explained as regular or predictable, origination from different, yet etymologically related sources of borrowing must be taken into consideration, as in an etymological dictionary, it is essential to distinguish between words originating from the same loan source and those originating from different ones. In fact, origination from different loan sources can also be an alternative explanation for "predictable" variants.

The variability of loanwords requires the special attention of an etymologist. To explain the reasons for variability, a detailed analysis of loanwords is required which takes into account their phonetic shape and areal distribution, as well as evidence from all the neighbouring languages. In this article, some examples of variability resulting from different loan sources will be analysed and some related problems will be introduced.

It should be mentioned that, in compiling the Estonian etymological dictionary, the published volumes (A-M) of the Estonian Dialect Dictionary (EMS) and the Concise Dialect Dictionary (VMS), as preorganized collections of dialect data, are of great help. In the Estonian Dialect Dictionary, there is a common principle according to which, if possible, all variants of a loanword are presented together in the same entry, but different ways or different times of borrowing and some other criteria are taken into account as well (EMS I: 21, see also Neetar 1992: 612-613). However, the solutions of the Estonian Dialect Dictionary cannot always be applied to an etymological dictionary. In the Concise Dialect Dictionary, which is just a preliminary entry list for the Estonian Dialect Dictionary, more variants of a loanword seem to be combined in the same entry. 


\section{Different quality of the stem-final vowel resulting from different loan sources}

In some cases, variants originating from different loan sources can be recognized by the quality of the stem-final vowel occurring in oblique cases. Having analysed the Germanic loanwords in Finnic languages, Vilhelm Thomsen concluded in the 19th century that the younger as well as older loanwords from the Nordic [i.e. Scandinavian] languages had preserved "full vowels" [i.e., $-a,-o$ and $-u$ ] at the end, while the (Low) German loanwords of Estonian and Livonian could be easily recognized by the $i$-ending as the equivalent of the German - $e$ (Thomsen 1967: 110). Later researchers noticed that the stem-final vowels $-a$ or $-u$ in Estonian cannot always be considered to be an obvious marker of Swedish or older Scandinavian/Germanic loanwords vs. Low German or German loanwords, because some of the latter still have stem-final $-a$ or $-u$ (see e.g., Ariste 1933: 28-29, Ariste 1937: 136, and Hinderling 1981: 113-116). However, Robert Hinderling has considered Finnish equivalents with the same stem-final vowel $[-a$ or $-u]$ to be a strong argument for the Swedish (or older Germanic) origin of such words (Hinderling 1981: 114). Dialectal variants of the words kann 'jug', nunn 'nun' and kirn 'churn' are classic examples of the variability resulting from different loan sources, reflected (mainly) in the quality of the stem-final vowel.

\section{1. kann 'jug'}

The word kann has, besides the $u$-final stem variant kann, g. kannu, belonging to the standard language, a dialectal $i$-final stem variant kann, g. kańni kanni, common in southern Estonian dialects and in the eastern dialect (EMS II: 676; see Map 1). Variants of this type occur in the same entry of the dialect dictionary (kann EMS II: 676). 


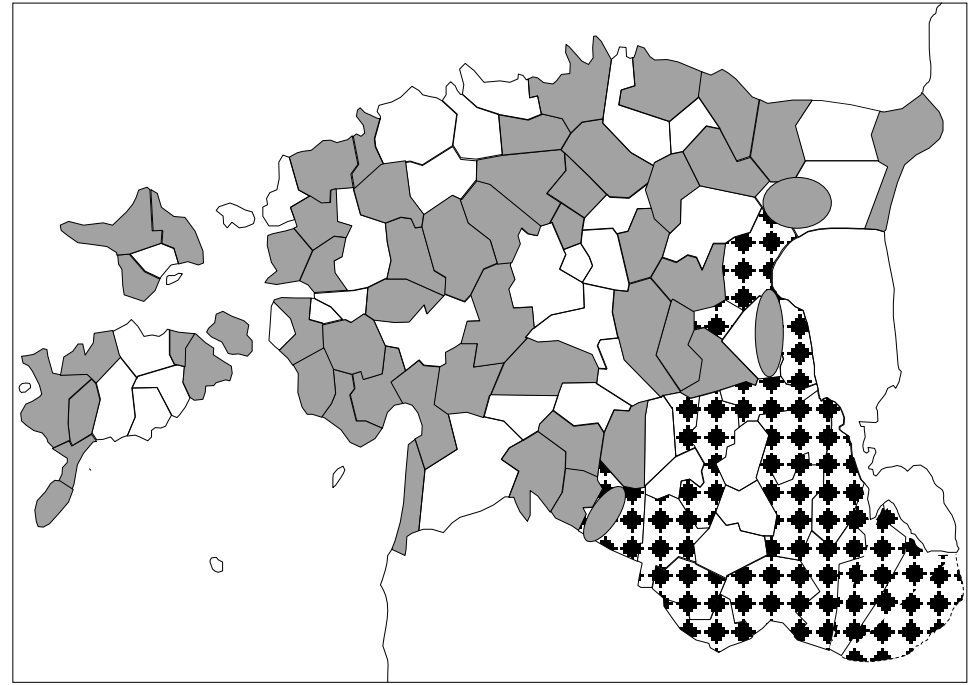

kann (kand) g. kannu

* kańn g. kańni (kanni)

Map 1. kann 'jug' in Estonian dialects.

The $u$-final stem is a Swedish (or even older, Scandinavian) loanword, < Swedish kanna 'jug' (Old Norse kanna). There is a $u$-final stem kannu in Finnish as well. The stem-final $-u$ in Estonian and Finnish (instead of the Old Norse and Swedish $-a$ ) is considered to reflect the word-final $-u$ of the oblique cases in Old Norse and Old Swedish (Thomsen 1967: 109). The $i$-final stem is borrowed from Middle Low German or (High) German, < Middle Low German kanne, German Kanne 'jug' (Thomsen 1967: 140, SKES: 156, EEW: 691, and SSA I: 300).

\section{2. nunn 'nun'}

In standard Estonian, the word for 'nun' has an $a$-final stem: nunn, g. nunna. The same form has been recorded in many sub-dialects sporadically over the language area (see Map 2). In several Estonian mainland sub-dialects, the noun has stem variants with final vowel -e (nunn, g. nunne) or $-i$ (nuńn, g. nuńni) (EMSUKA). The $e$-final variant is also seen in the street name Nunne in Old Tallinn. The $a$-final stem is an Old Swedish loanword, < Old Swedish nunna, nonna 
'nun', cf. also Finnish nunna. The $e$ - and $i$-final stem originate from Middle Low German nunne id. (EEW: 1742, Raag 1988: 659, 661).

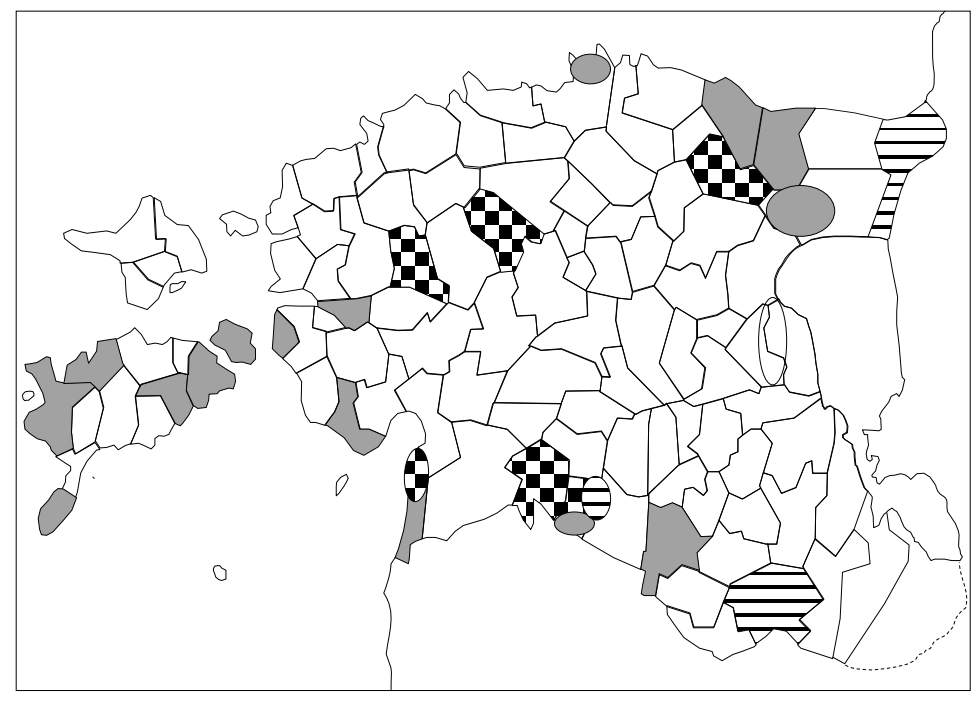

g. nunna

g. nunne

g. nunni

Map 2. nunn 'nun': the vocal stems in Estonian dialects.

\section{3. kirn 'churn'}

The word for 'churn (wooden vessel for keeping milk or cream, etc.)' has the variants kirn, g. kirnu, kern, g. kernu, kärin, g. kärni, and käärne in Estonian dialects (see Map 3), i.e. besides the different quality of the stem-final vowel, there are also other phonetic differences in the stem (EMS III: 230, and EMS IV: 501, 587). The variant kirn, g. kirnu is an Old Swedish (or Scandinavian) loanword < Old Swedish kirna 'churn' (Old Norse kirna) (SKES: 199, Hinderling 1981: 171-172, EEW: 847, and SSA I: 371), cf. also Finnish kirnu. The variant kern, g. kernu is connected with kirn, as the change ir $>$ er is typical of northern Estonian dialects (EEW: 847, and Kask 1972: 125). The variant kärn, g. kärni has been borrowed from Middle Low German kerne, kirne (Hinderling 1981: 183, and EEW: 847). In addition to the variants borrowed from different Germanic languages, there is also a variant käärne, occurring only in the Leivu linguistic enclave in Latvia. This has been borrowed via Latvian, < Latvian dial. ķęrne 
(Vaba 1997: 306). (After the example päälitse käärne, presented by Vaba (1997: 306), käärne seems to be n. pl., and there is also a n. sg. form käärnä in Leivu.) In the Estonian Dialect Dictionary, there are the entries kirn (including kern) (EMS III: 230-231), kärn (EMS IV: 501) and käärne (EMS IV: 587); thus the entries match the different etymologies of the variants.

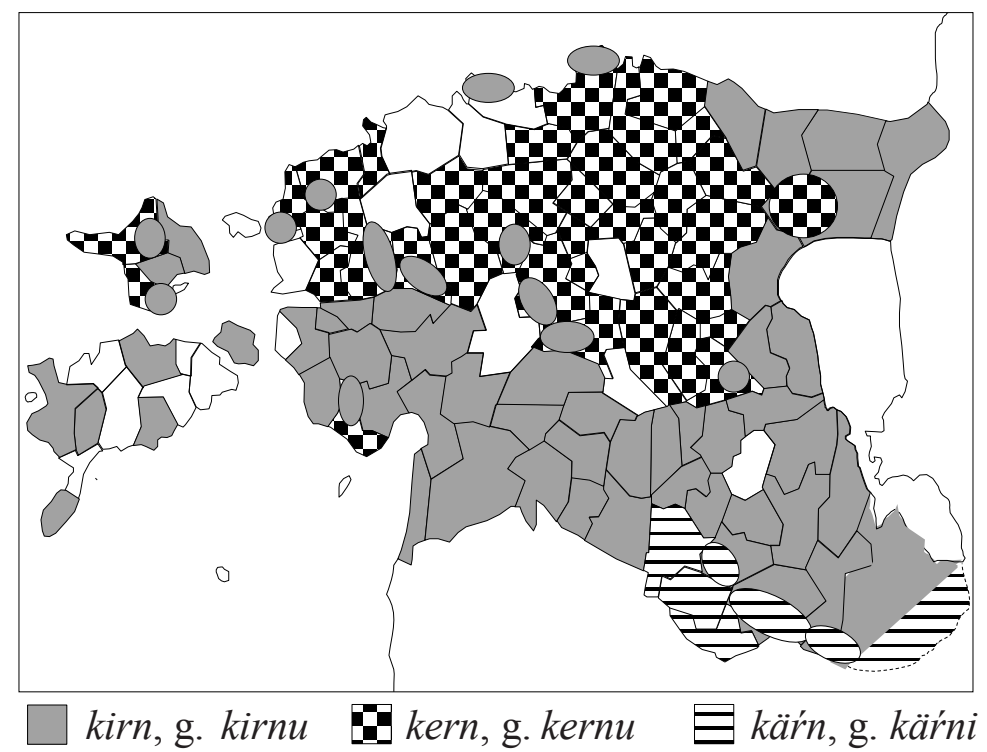

Map 3. kirn 'churn': variants in Estonian dialects.

\section{Other kinds of variability in the stem shape}

More extensive variability in the stem shape is much more common. Sometimes the different loan sources of the variants are quite transparent, while sometimes the variants can be interpreted in several ways. Often the situation is also complicated by variability in the donor language. If certain phonetic criteria are lacking, some conclusions about the possible loan sources may be drawn from the areal distribution of the variants. 


\section{1. kartul 'potato'}

The word kartul 'potato' has the dialect variants kardul(as), kardules, kardulis, karduhvel, kartles, tuhl(is), tohris, toh(v)el, tih(v)el, kartohk, kardohk, kardok etc. (EMS II: 768, 769, 771, 772, and VMS I: 181, II: 553; about the dialectal distribution of the variants see ALFE 2: 51). In the Estonian Dialect Dictionary, there are the entries kartul (EMS II: 772-773), kartuhvel (EMS II: 771-772), kartles (EMS II: 768) and kartohk (EMS II: 769) for the kar-initial variants of the word (five volumes of the dictionary $\mathrm{A}-\mathrm{M}$ have been published so far). Considering the etymology, the variants kartul, kartuhvel and kartles originate from the same loan source ( $<$ German Kartoffel 'potato') (EEW: 719). The origin of the word tuhlis and other short variants without the initial syllable kar-is problematic. On the one hand, they may also originate from the same source (cf. EEW: 3324), as the loss of the unstressed first syllable of the loan source is common in Estonian. On the other hand, in German the dialectal variants Toffel, Toffelchen, Tyft and Tofels (DWB, s.v. Tuffel, Viereck 2011: 11, cf. also Raun 1982: 183) have also been recorded. Thus the Estonian short variants may have also been borrowed from a German variant as developed in Estonian. There seems to be no doubt that the words kartohk, kardohk, kartokass and kardokas, common in the Vorru dialect of South Estonian, are borrowed via Russian (< Russian kartófel', dialectal kartóvka, kartóxa 'potato') (Must 2000: 87).

\section{2. kapsas 'cabbage'}

The word kapsas 'cabbage' has the variants kapst(ass), kapust(as), kapus, kaapsas, kaapsus, kuastas etc. (EMS II: 712, 715, 717, and EMS III: 927; see Map 4). In the Estonian Dialect Dictionary, there are the entries kapsas (including the variants kaapsas and kaapsus with a long vowel in the first syllable) (EMS II: 712-713), kapst(ass) (EMS II: 715), kapus and kapust(as) (EMS II: 717) and kuastas (EMS III: 927). In terms of etymology, the variants kapsas, kapst(ass), kapust(as) and kapus originate from the Russian kapústa 'cabbage', reflecting the different stages of the adaptation of the loanword (kapusta $>$ kap $(u)$ st $>$ kapst $>$ kapstas $>$ kapsas) (Must 2000: 79-80). The variants kaapsas, kaapsus and kuastas, common in the insular dialect and in the western dialect, may have been borrowed via Latvian (<kāposti pl. id.), or at 
least they have been influenced by the Latvian word, as Mari Must and Lembit Vaba have claimed (Must 2000: 79-80 and Vaba 1997: 78-79).

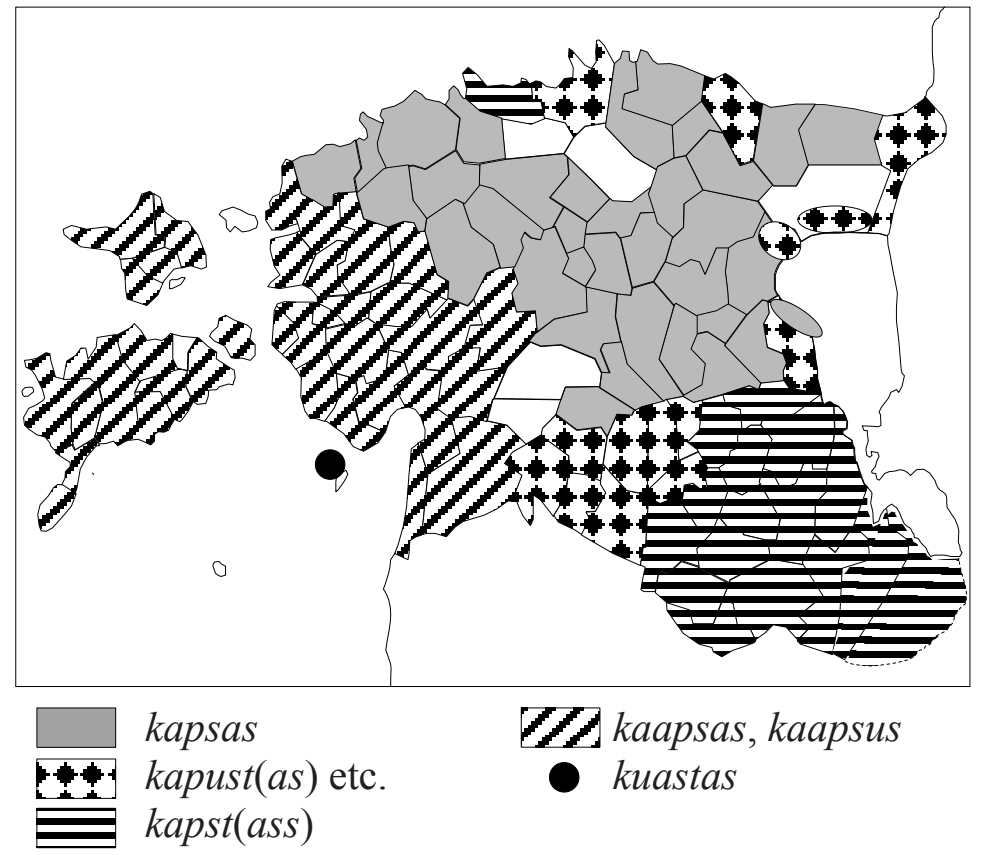

Map 4. kapsas 'cabbage' in Estonian dialects.

\section{3. reetkamm 'reed'}

The word reetkamm 'reed, used in winding warp threads on a warp beam' has the variants reekkamm, reekamm, reet, reigam $(m)$, reikkam $(m)$ etc. (EMSUKA, cf. also VMS II: 317; see Map 5). 


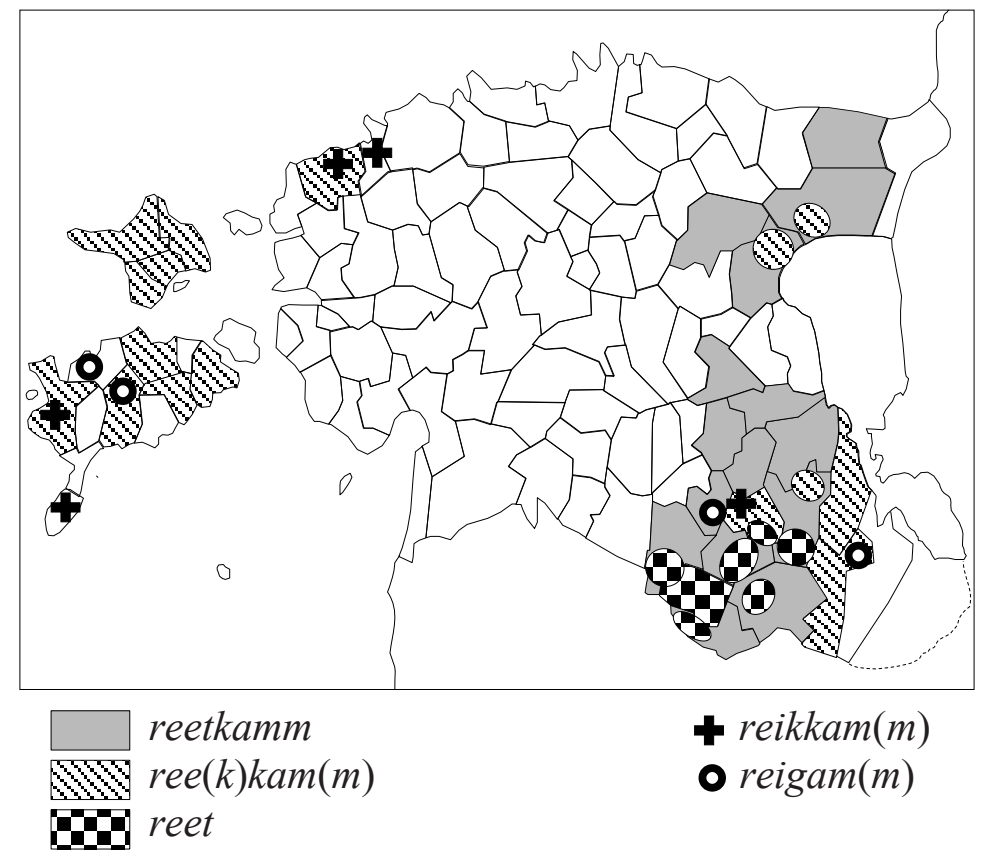

Map 5. reetkamm 'reed': variants in Estonian dialects.

The word reetkamm is considered to be a Low German loanword (Ariste 1933: 98, cf. also Koponen 1998: 157), < Middle Low German rếdekam 'kammförmiges Brett zum aufbringen des Kettgarns auf den Webstuhl' (LB II: 1960). The Swedish redkam could be the source, too, but the Swedish word has itself probably been borrowed from Middle Low German (SAOB, s.v. redkam). The variants reekkam (m), reekam $(m)$ and reet are probably connected with reetkamm, the first two variants having developed as a result of assimilation, and the last one having lost the second component of the compound word. The variants reigam $(\mathrm{m})$ and reikkam $(\mathrm{m})$, recorded in the insular dialect and in north-west Estonia, have been borrowed from Estonian-Swedish dialects, according to Paul Ariste (1933: 97). The loan source is the Estonian-Swedish raikåmb, rai(j)kåmb, räikám, räi(j)kam, roẹ-komb, roe-komb 'vävsked', English 'weaver's comb, reed' (Freudenthal and Vendell 1886: 169, 178, Vendell 1906: 739, Danell 1951: 322, and Isberg 1970: 253). However, it is difficult to explain the variants reigamm from Põlva and reikamm from Kanepi in southern Estonia as Estonian-Swedish loanwords. As there seems to be some evidence of variants with diphthongs in Low German as well, cf. rếidekam, noted before, and reit (SAOB, s.v. redkam), it cannot be excluded that the 
Estonian dialectal variants with diphthongs may have been borrowed from a Low German source. In Julius Mägiste's opinion, reigam has developed from reetkamm as a result of contraction (EEW: 2441). Considering the variants reigam $(m)$ and $\operatorname{reikkam}(m)$, recorded in the insular dialect and in north-west Estonia, the Estonian-Swedish origin is certainly the most plausible.

\section{A complicated group of loanwords from different sources: words for 'shuttle'}

The analysis of a larger group of words with similar construction and denoting the same object illustrates the complicated lexical relations of Estonian dialects. In dialect dictionaries, there are the following words for 'shuttle': kotspool (kotspuul and kootspool), kutspool, kujutspool (VMS I: 285, 309, see also EMS III: 640, 764, 983 and EMS IV: 133), otspool (atspool, otspul, otspol and otpuul) (VMS II: 153), sits, sitspool (setspool), sitspuur and sutspool (so(o)tspo(o)l) (VMS II: 421, 447). In addition to those mentioned above, derivatives from the verb süst-, sööst- 'to dash, to rush; to dart; to throw oneself into something' are used for 'shuttle' (VMS II: 467, 471). The first component of all these compounds ends with $-t s$, and the second component is -pool (often in shortened form). Besides the words evidently originating from different but etymologically connected sources, words or variants occur that probably developed in Estonian dialects.

Different words may reflect different types of shuttles, e.g.

Käina Kui surnuk on mõlemalt poolelt lahti, siis on see süstik. Kui aga teine pool on kinnine, siis kutsutakse sitspol ['If both sides of a shuttle are open, it is called süstik. But if one side is closed, it is called sitspol']

Viru-Nigula taval. suts-pool surnukas, kutspool harva ['usually sutspool surnukas, seldom kutspool']

Haljala kotspual (sõna tarvitasid ainult kangrud) ['the word was used only by weavers']

Nõo kotspool (uuem) süstik ['kotspool (younger) süstik']

(EMSUKA)

On the basis of the information in the archive of the Estonian dialects, no clear connections can be seen between different types and designations.

Next the names for shuttle will be discussed in more detail. 


\section{1. kotspool, kutspool etc.}

The shuttle names kotspool (kotspuul and kootspool) and kutspool occur on the north-eastern and north-western coasts of Estonia, in south-western Estonia and in the Mulgi and Tartu dialects of the South Estonian group (Map 6). The words kutspool and kotspool were recorded in A. W. Hupel's dictionary (1790: 190). According to Andrus Saareste (1924: 231), these words have been borrowed from local Estonian Swedes on the coast, and from Swedish weavers who worked in towns in southern Estonia, < Swedish skottspole 'shuttle' (parts of the compound skott 'shot' + spole 'spool, reel, bobbin; shuttle'). The Estonian-Swedish variants are skotspól, sküttspól, skwtspwl and skutsp $\omega l$ 'skottspole and vävskyttel' (Freudenthal and Vendell 1886: 194, 197, Danell 1951: 358, and Isberg 1970: 282). The word kutspool is also mentioned as a Swedish loanword later in the book Kaunis emakeel by Andrus Saareste $(1952: 61,81)$ and in Introduction to Estonian linguistics by Alo Raun and Andrus Saareste (1965: 45).

Wilhelm Wiget (1928: 261-262) has mentioned that the areal distribution of the words kutspool, kootspool and kotspuul is not typical for an Estonian-Swedish loanword. Paul Ariste in his master's thesis on Estonian-Swedish loanwords does not discuss the problems of origin in detail, considering the variants kutspool, kootspool, kootspuul etc. to be Estonian-Swedish loanwords (Ariste 1933: 70). In Julius Mägiste's Estnisches etymologisches Wörterbuch, the etymology of the word kuts(in the compound kutspool) is missing (EEW: 1069). It is unclear how to explain the occurrence of an (Estonian-)Swedish loanword in the Mulgi and Tartu dialects.

Considering the distribution of variants with $u$ and $o$ in the first syllable, one can notice variants with $o$ occurring in southern Estonia. According to Saareste's explanation, the word arrived in southern Estonia from Swedish weavers in towns. In Estonian-Swedish dialects, the vowels $o$ and $\omega$ may vary in the first syllable, and this can also be reflected in the words borrowed by Estonian. P. Ariste has mentioned the words kutspool $\sim$ kotspuul as an example of the phenomenon (Ariste 1933: 18-19).

There is some variation $o \sim u$ in the first syllable in Estonian dialects, too. This is primarily characteristic of western Estonia, in particular in the western dialect, as well as in the insular dialect and in part of the central dialect influenced by the western dialect; the vowel $o$ may be raised or replaced with $u$ and, vice versa, the vowel $u$ may 
be lowered or replaced with $o$ (Juhkam and Sepp 2000: 15, and Must 1965: 14; see also Lonn and Niit 2002: 26, 27-28).

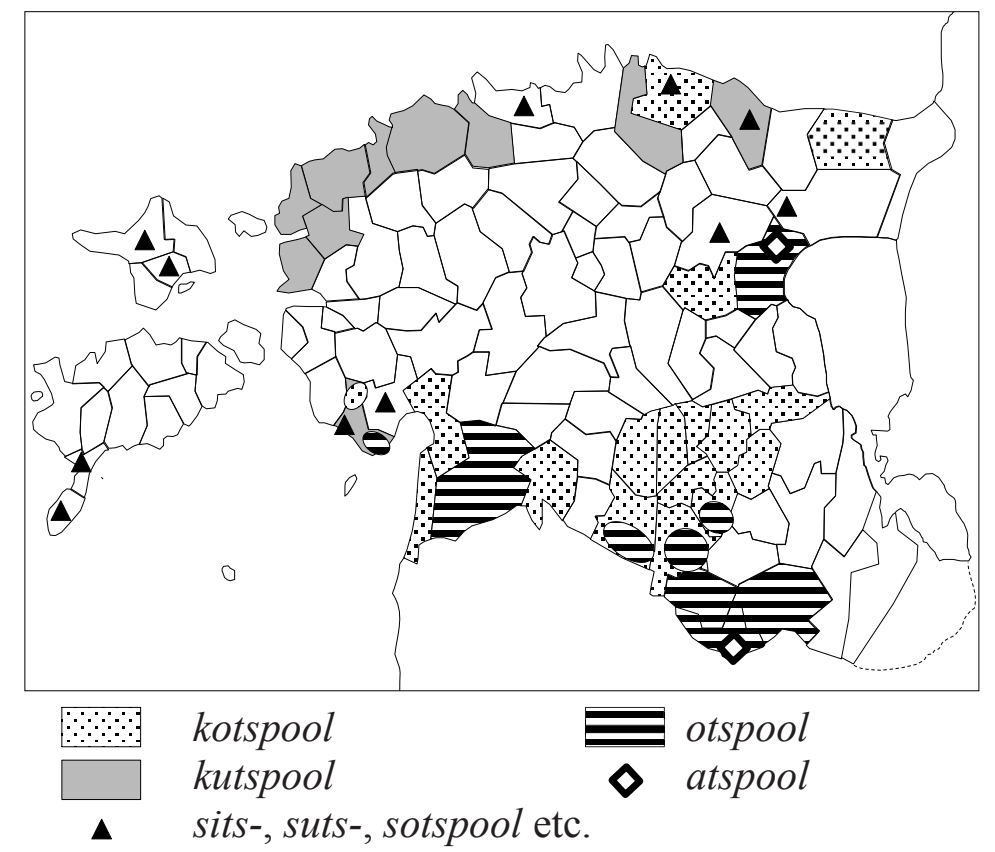

Map 6. 'shuttle' in Estonian dialects.

There is a similar word schotspole 'Weberspule, Weberschiffchen' (SchL IV: 126), schotspôle (-spoele), -sprile 'Schießspule, Weberschiffchen' (LB III: 133) in Middle Low German. The origin of the word from a Low German source is another and even more plausible explanation. In Middle Low German loanwords, the cluster sch- is usually replaced by $k$ - in Estonian (Ariste 1972: 92). The same word has been recorded in German dialects in Westphalia: schotspaule 'weberschifflein' (Woeste 1882: 230). Thus we suggest that the variant kotspool in the Tartu and Mulgi dialects may be a Middle Low German loanword.

\section{2. sutspool, sotspool, sitspool etc.}

The $s$-initial words for 'shuttle' sutspool (so(o)tspo(o)l), sitspool (setspool), sits, sitsper and sitspuur occur sporadically in northern 
Estonian dialects, as can be seen in Map 6 (VMS, EMSUKA). The words sotspool and sutspool are recorded in Wiedemann's EstonianGerman Dictionary (Wiedemann 1869: 1170, 1207; Wiedemann 1973: 1062, 1094), and there is the variant sütspool (= süstepool) (Wiedemann 1869: 1217 and Wiedemann 1973: 1102). The earliest documentation of the word sutspool known to us is from 1849 in the book Ma-ilm ja mõnda, mis seal sees leida on, by Fr. R. Kreutzwald (MM 148).

A. Saareste (1924: 232) also examined the origin of these words. He assumed that the words setspool, sitspool, sitspuur, sutspool and süts may have developed as a contamination of the types otspool and süstpool, but more likely the types otspool and kutspool, kotspool have been influenced by the language of the weavers in towns and manors and the German Schütze 'shuttle'. J. Mägiste (EEW: 3016) has connected the words süts-pool, sots-pool and suts-pool with the German Schütz-spule. There is Schütze 'shuttle' in German (e.g. DWB 'als webergerät'), but the compound Schütz(-)spule is not found in dictionaries. ALFE 3 (400406) regards these $s$-initial words as variants of the words for 'shuttle', derived from the Estonian verb stem sööst- 'to dash, to rush; to dart; to throw oneself into something' (cf. e.g., süst, süstipuu, süst(i)pool, söösti(pool), sööstipuu etc.). However, it is mentioned that they may also include components of other etymologies.

Actually, all the s-initial words mentioned here (sutspool (so(o)tspo(o)l), sitspool (setspool), sütspool etc.) can be considered to be borrowings from German. In addition to the German Schütze (Schütz-spule), mentioned by Julius Mägiste (EEW: 3016), the variant Schutze 'shuttle' is recorded in Middle High German (Lexer 1876: 835 and Köbler 2013), and in W. v. Gutzeit's dictionary of Baltic German there is Schutzspule (Gutzeit 1898: 170). (Unfortunately, no definition is given for the word, but there is an example of its usage: Arbeit, so auf dem Stuhl und auf dem Schragen mit dem Schutz Spuhlen gemachet werden kann.) Note that in Baltic German there was a tendency of delabialization of front vowels, according to which $i$ was often pronounced instead of $\ddot{u}$, thus Schütze, Schütz-spule could actually have been pronounced with $i$ (Mitzka 1923: 22). There are also the words Schoßspule and Schießspule for 'shuttle' in German. All of these German words should be taken into account as loan sources of Estonian words.

The variation $i \sim e$ (sitspool $\sim$ setspool) is probably local: the vowel $i$ may lower in the western dialect and in the part of the central 
dialect influenced by the western dialect (Must 1965: 14 and Pajusalu et al. 2009: 137).

In conclusion, it is probable that the loan source of the Estonian dialect word sutspool is the German Schutzspule, Schutze; the word sotspool may be a result of local variation $o \sim u$, but its source may also be the German Schoßspule. The word sitspool may be borrowed via the Baltic German dialect from the word Schütze, but the influence of the German Schießspule is possible as well. The variant setspool has developed due to local variation $i \sim e$.

Probably the $s$-initial Estonian words have been borrowed from several sources. Contaminations and mutual influences of different words have had some role, too. The first components of all the German words listed here are etymologically connected with each other, as well as with the Low German schotspole and Swedish skottspole.

\section{3. atspool, otspool}

The word atspool, recorded in two parishes (Torma and Rõuge; see Map 6), is a Latvian loanword, as mentioned by Andrus Saareste (1924: 232) and confirmed by Lembit Vaba (1997: 66-67), < Latvian atspuõle 'Weberschiffchen, Garnspulchen' (ME I: 196). The Latvian word, in turn, has been borrowed from Low German, < schotspole (i.e., from the same source suggested for the Estonian kotspool above), but the first component of the Low German compound has been replaced by the Latvian prefix at- (Sehwers 1953: 4 and Vaba 1997: 66).

The word otspool is recorded in the Tõstamaa and Saarde parishes of the western dialect and in some parishes of the Tartu and Vorru dialects (Map 6).

In Andrus Saareste's opinion (1924: 231-232), the word otspool has the same source as the word atspool, while $o$ has developed under the influence of the words ots 'end' and kotspool. Lembit Vaba has argued that it is not necessary to suppose a borrowing before the contamination: otspool has, rather, developed directly from kotspool-type words and has been associated folk-etymologically with the word ots (Vaba 1997: 66-67). Some influence of the Latvian loanword can still be assumed in the neighbouring area of the word atspool. 


\section{4. kujutspool, lutspool and potspuol}

Three compounds with the second component -pool have been recorded only once, each in a different sub-dialect. The word kujutspool has been recorded only in the Saarde parish of the western dialect. According to Andrus Saareste, this variant has developed due to folk etymology. The first component has been associated with the verb kuduma 'to weave; to knit', and the present sg3P is kujub in the western dialect (Saareste 1924: 231; see also Wiget 1928: 262). Probably it has been influenced by the variant kootspool of kotspool (see also 4.1), pronounced as kuutspuul, kuutspuul in Häädemeeste, next to Saarde.

Two words with different first components but the same second component have been recorded in the North Estonian coastal dialect: lutspool (Viru-Nigula) and potspuol (Haljala) (Saareste 1924: 228, EMS V: 531 and EMSUKA). A. Saareste (1924: 231) thinks these variants (luts- and pots-) have developed from onomatopoetic interjections. The only recording of the word lutspool, found in the archive of the Estonian dialects, contains the explanation muistne põhjaga süstik, tarvitusel oli antvärgi rahval ('an ancient shuttle with bottom or base, used by handicraftsmen'). The word potspuol may be just accidental pronunciation.

\section{Conclusion}

The variability of loanwords in Estonian dialects has often resulted from different but mutually etymologically connected loan sources, as there are loanwords from several contact languages with diverse mutual relations. However, there are also other reasons for variability, and thus, the variability requires the etymologist's special attention. A detailed analysis of the phonetic shape and areal distribution of dialect words/variants and their comparison with the evidence of contact languages makes it possible to discover different loan sources if certain phonetic or geographical criteria can be applied. In many cases, such criteria are difficult to find, and the variability can be interpreted in several ways. In addition, more detailed comparison inside different loanword groups, with the loanwords having well-established etymologies, would probably help to elaborate the criteria and produce more results. 


\section{Acknowledgements}

The study was partly supported by the Estonian Science Foundation grant nr 9367.

\section{Addresses}

Iris Metsmägi, Meeli Sedrik and Vilja Oja

Institute of the Estonian Language

Roosikrantsi 6

10119 Tallinn, Estonia

E-mail: iris.metsmagi@eki.ee, meelisedrik@hot.ee, viljaoja@eki.ee

\section{Abbreviations}

g. - genitive, n. - nominative, pl. - plural, sg. - singular, $3 \mathrm{P}-3$. person

\section{References}

ALFE 2 = Atlas Linguarum Fennicarum. Itämerensuomalainen kielikartasto. Läänemeresoome keeleatlas. Ostseefinnischer Sprachatlas. Lingvističeskij atlas pribaltijsko-finskix jazykov. 2. Editor-in-chief Tuomo Tuomi; 2nd volume edited by Tiit-Rein Viitso. (Suomalaisen Kirjallisuuden Seuran Toimituksia, 800. Kotimaisten kielten tutkimuskeskuksen julkaisuja, 118.) Helsinki: Suomalaisen Kirjallisuuden Seura; Kotimaisten kielten tutkimuskeskus, 2007.

ALFE 3 = Atlas Linguarum Fennicarum. Itämerensuomalainen kielikartasto. Läänemeresoome keeleatlas. Ostseefinnischer Sprachatlas. Lingvističeskij atlas pribaltijsko-finskix jazykov. 3. Editor-in-chief Tuomo Tuomi; 3rd volume edited by Vladimir Rjagojev. (Suomalaisen Kirjallisuuden Seuran Toimituksia, 1295, Tiede. Kotimaisten kielten tutkimuskeskuksen julkaisuja, 159.) Helsinki: Suomalaisen Kirjallisuuden Seura, Kotimaisten kielten tutkimuskeskus, 2010.

Ariste, Paul (1933) Eesti-rootsi laensõnad eesti keeles. (Tartu Ülikooli toimetused. Acta et Commentationes Universitatis Tartuensis (Dorpatensis), B XXIX.3.) Tartu.

Ariste, Paul (1937) “Mõningaid alamsaksa laensõnu”. Eesti Keel, 5, 132-140.

Ariste, Paul (1972) "Das Niederdeutsche im Estnischen". Sovetskoe finno-ugrovedenie VIII, 2, 91-99.

Danell, Gideon (1951) Ordbok över Nuckömålet. (Estlandssvenskarnas folkliga Kultur II. Skrifter utgivna av Kungl. Gustav Adolfs Akademien, 27.) Lund. 
DWB = Das Deutsche Wörterbuch von Jacob und Wilhelm Grimm auf CD-ROM und im Internet. Available online at $<\mathrm{http} / /$ germazope.uni-trier.de/Projekte/DWB $>$. Accessed on 20.04.2014.

EEW = Mägiste, Julius (1982-1983) Estnisches etymologisches Wörterbuch . Helsinki: Finnisch-Ugrische Gesellschaft.

EMS $=$ Eesti murrete sõnaraamat. I-V. Eesti Teaduste Akadeemia. Eesti Keele Instituut. Tallinn: Eesti Keele Sihtasutus, 1994-2013.

EMSUKA = Eesti murrete ja soome-ugri keelte arhiiv. (The archive of the Estonian and Finno-Ugric languages.) Institute of the Estonian Language, Tallinn.

Freudenthal, A. O. and H. A. Vendell (1886) Ordbok öfver estländsk-svenska dialekterna. (Skrifter utgifna af Svenska literatursällskapet i Finland, VII.) Helsingfors: Tidnings- \& tryckeri-aktiebolagets tryckeri.

Gutzeit, W. v. (1898) Wörterschatz der Deutschen Sprache Livlands. Nachträge zu $A-V$. Riga: In Commission bei N. Kymmel. Available online at $<$ http://digar.nlib.ee/digar/show/?id=14491>. Accessed on 20.04.2014.

Hinderling, Robert (1981) Die deutsch-estnischen Lehnwortbeziehungen im Rahmen einer europäischen Lehnwortgeographie. Wiesbaden: Otto Harrassowitz.

Hupel, August Wilhelm (1780) Ehstnische Sprachlehre fur beide Hauptdialekte, den revalschen und den dorptschen; nebst einem vollständigen Worterbuch. Riga und Leipzig: bey Johann Friedrich Hartknoch. Available online at $<$ http://books.google.ee/books?id=RmIUAAAAQAAJ\&printsec=frontcover\& source $=\&$ redir_esc $=\mathrm{y} \# \mathrm{v}=$ onepage $\& \mathrm{q} \& \mathrm{f}=$ false $>$. Accessed on 20.04.2014.

Isberg, Fridolf (1970) Supplement till G. Danells ordbok över Nuckömålet. 1: A-L, 2: M-Ö. (Acta Academiae Regiae Gustavi Adolphi, XLVII.) Uppsala: AB Lundequistska bokhandeln.

Juhkam, Evi and Aldi Sepp (2000) Läänemurde tekstid. (Eesti murded VIII.) Eesti Keele Instituut. Tallinn.

Kask, Arnold (1972) Eesti keele ajalooline grammatika I. Häälikulugu. [2nd edition.] Tartu: Tartu Riiklik Ülikool, eesti keele kateeder.

Koponen, Eino (1998) Eteläviron murteen sanaston alkuperä. Itämerensuomalaista etymologiaa. (Suomalais-Ugrilaisen Seuran toimituksia. Mémoires de la Société Finno-Ougrienne, 230.) Helsinki: Suomalais-Ugrilainen Seura.

Köbler, Gerhard (2013) Mittelhochdeutsches Wörterbuch. 2. A[uflage]. Available online at <http://www.koeblergerhard.de/germanistischewoerterbuecher/ mittelhochdeutscheswoerterbuch/mhdwbhin.html>. Accessed on 20.04.2014.

LB II = Mittelniederdeutsches Handwörterbuch. Begründet von A. Lasch und C. Borchling. Dieter Möhn, Hg. Band II. Neunundzwanzigste/Dreißigste Lieferung. quâdâine bis rếp. Neumünster: Wachholtz Verlag, 2002.

LB III = Mittelniederdeutsches Handwörterbuch. Begründet von A. Lasch und C. Borchling. Dieter Möhn, Hg. Band III. Zwölfte Lieferung. Sâbâot bis schôt. Neumünster: Karl Wachholtz Verlag, 1959. 
Lexer, Matthias (1876) Mittelhochdeutsches Handwörterbuch. Zugleich als Supplement und alphabetischer Index zum Mittelhochdeutschen Wörterbuche von Benecke-Müller-Zarncke. Zweiter Band. Leipzig: Verlag von S. Hirzel.

Lonn, Varje and Ellen Niit (2002) Saarte murde tekstid. (Eesti murded VII.) Eesti Keele Instituut. Tallinn.

ME I = K. Mülenbacha Latviešu valodas vārdnīca. I sējums. K. Mühlenbachs Lettisch-deutsches Wörterbuch. I Band. Rediǵējis, papildinājis, turpinājis J. Endzelīns. Redigiert, ergänzt und fortgesetzt von J. Endzelin. Riga, 1923-1925.

Mitzka, Walter (1923) Studien zum baltischen Deutsch. (Deutsche Dialektgeographie. Berichte und Studien über G. Wenkers Sprachatlas des Deutschen Reichs herausgegeben von Ferdinand Wrede. Heft XVII.) Marburg: N. G. Elwert'sche Verlagbuchhandlung.

$\mathrm{MM}=$ Ma-ilm ja mõnda, mis seal sees leida on. Faksiimiletrükk on pühendatud Fr. R. Kreutzwaldi 200. sünniaastapäevale. Tallinn: Eesti Rahvusraamatukogu, 2003. Available online at $<\mathrm{http}: / /$ digar.nlib.ee/digar/show/?id=222>.

Accessed on 20.04.2014.

Must, Mari (1965) Keskmurde tekstid. (Eesti murded II.) Eesti NSV Teaduste Akadeemia Keele ja Kirjanduse Instituut. Tallinn.

Must, Mari (2000) Vene laensõnad eesti murretes. Tallinn: Eesti Keele Sihtasutus.

Neetar, Helmi (1992) "Etymologisches im estnischen Dialektwörterbuch (EDW)". In Euralex '92. Proceedings I-II. Papers submitted to the 5th EURALEX International Congress on Lexicography in Tampere, Finland, 607-614. Tampere.

Pajusalu, Karl, Tiit Hennoste, Ellen Niit, Peeter Päll and Jüri Viikberg (2009) Eesti murded ja kohanimed. 2., täiendatud trükk. Tartu Ülikooli eesti ja üldkeeleteaduse instituut, Eesti Keele Instituut. Tallinn: Eesti Keele Sihtasutus.

Raag, Raimo (1988) "Nunn, prilla, koka ja teised. Eesti keele rootsi laensõnadest". Keel ja Kirjandus, 11-12, 655-664, 725-732.

Raun, Alo (1982) Eesti keele etümoloogiline teatmik. Rooma-Toronto: Maarjamaa.

Raun, Alo and Andrus Saareste (1965) Introduction to Estonian Linguistics. (Uralaltaische Bibliothek, 12.) Wiesbaden.

Saareste, Albert (1924) Leksikaalseist vahekordadest eesti murretes. I. Analüüs. 60 kaardi ja 1 skeemiga. (Eesti Vabariigi Tartu Ülikooli Toimetused. Acta et Commentationes Universitatis Dorpatensis, B VI.1.) Tartu.

Saareste, Andrus (1952) Kaunis emakeel. Vesteid eesti keele elust-olust. Lund.

$\mathrm{SAOB}=$ Svenska Akademiens ordbok. Available online at

$<$ http://g3.spraakdata.gu.se/saob/>. Accessed on 20.04.2014.

SchL $=$ Schiller, K. and A. Lübben (1875-1881) Mittelniederdeutsches Wörterbuch . Available online at $<\mathrm{http}: / /$ www.rzuser.uni-heidelberg.de/ cd2/drw/s/Sa-schm.htm\# Schiller-Lubben>. Accessed on 20.04.2014.

Sehwers, Johannes (1953) Sprachlich-kulturhistorische Untersuchungen vornehmlich über den deutschen Einfluss im Lettischen. 2. Auflage. Unveränderter Neudruck der 1936 erschienenen ersten Auflage. (Veröffentlichungen der Abteilung für Slavische Sprachen und Literaturen des Osteuropa-Instituts (Slavisches Seminar) 
an der Freien Universität Berlin. Band 4.) Berlin: In Commission bei Otto Harrassowitz Wiesbaden.

SKES = Erkki Itkonen, Yrjö H. Toivonen and Aulis J. Joki (1955-1981) Suomen kielen etymologinen sanakirja. (Lexica Societatis Fenno-Ugricae, XII, 2. Tutkimuslaitos "Suomen Suvun" julkaisuja, III.) Helsinki.

SSA = Suomen sanojen alkuperä. Etymologinen sanakirja. Edited by E. Itkonen, U.-M. Kulonen. (Suomalaisen Kirjallisuuden Seuran toimituksia, 556. Kotimaisten kielten tutkimuskeskuksen julkaisuja, 62.) Helsinki: Suomalaisen Kirjallisuuden Seura, Kotimaisten kielten tutkimuskeskus, 1992-2000.

Thomsen, Vilhelm (1967 [1870]) On the influence of germanic languages on finnic and lapp. A historical linguistic inquiry. With an introduction by Thomas A. Sebeok. [A photolithographic reproduction of the German translation from Danish, published in Halle, 1870.] (Indiana University Publications. Uralic and Altaic Series, 87.) Bloomington, The Hague: Indiana University, Mouton \& Co.

Vaba, Lembit (1997) Uurimusi läti-eesti keelesuhetest. Eesti Keele Instituut. Tampereen yliopiston suomen kielen ja yleisen kielitieteen laitos. Tallinn, Tampere.

Vendell, Herman (1906) Ordbok över de östsvenska dialekterna. Tredje häftet. (Skrifter utgifna af Svenska literatursällskapet i Finland, LXXV.) Helsingfors: Tidnings- \& tryckeri-aktiebolagets tryckeri.

Viereck, Wolfgang (2011) "The Atlas Linguarum Europae as an Instrument for Eurolinguistic Research". Journal for EuroLinguistiX 8, 1-33. Available online at $<$ http://www1.ku-eichstaett.de/SLF/EngluVglSW/ELiX/index.htm>. Accessed on 20.04.2014.

VMS = Väike murdesõnastik. I-II (1982-1989) Ed. Valdek Pall. Eesti NSV Teaduste Akadeemia Keele ja Kirjanduse Instituut. Tallinn: Valgus. Available online at $<$ http://portaal.eki.ee/dict/vms $>$. Accessed on 20.04.2014.

Wiedemann, Ferdinand Johann (1869) Ehstnisch-deutsches Wörterbuch. St. Peterburg: Buchdruckerei der Kaiserlichen Akademie der Wissenschaften. Available online at

$<$ http://books.google.ee/books?id=FdBEAAAAcAAJ\&printsec=frontcover\&source $=\&$ redir_esc $=\mathrm{y} \# \mathrm{v}=$ onepage $\& \mathrm{q} \& \mathrm{f}=$ false $>$. Accessed on 20.04.2014.

Wiedemann, Ferdinand Johann (1973) Eesti-saksa sõnaraamat. Neljas, muutmata trükk teisest, Jakob Hurda redigeeritud väljaandest. Estnisch-deutsches Wörterbuch. Vierter unveränderter Druck nach der von Jakob Hurt redigierten Auflage [1893]. Tallinn: Valgus.

Wiget, Wilhelm (1928) "Herkunft und Verbreitung der neueren germanischen Lehnwörter im Estnischen". Õpetatud Eesti Seltsi aastaraamat. Sitzungsberichte der Gelehrten Estnischen Gesellschaft 1927, 255-275. Tartu: K. Mattiesen'i trükk.

Woeste, Fr. (1882) Wörterbuch der westfälischen Mundart. Norden und Leipzig: Diedr. Soltau's Verlag. Available online at $<$ https://archive.org/stream/wrterbuchderwes00spragoog\#page/n10/mode/1up $>$. Accessed on 20.04.2014. 
Kokkuvõte. Iris Metsmägi, Meeli Sedrik, Vilja Oja: Erinevad laenuallikad eesti murdesõnade variatiivsuse põhjusena. Üks laensõnade häälikulise varieeruvuse põhjusi eesti murretes on pärinemine erinevatest, kuid omavahel etümoloogiliselt seotud laenuallikatest. Etümoloogilistes sõnaraamatutes on eri laenuallikaist pärit sõnade eristamine põhimõttelise tähtsusega. Artiklis analüüsitakse niisugusest aspektist mõningaid (murde)sõnu ja nende variante. Eri laenuallikate tuvastamiseks on sageli kasutatud konkreetseid kriteeriume, nt sõnade kann, nunn ja kirn murdevariantide etümologiseerimisel on lähtutud tüvevokaalist. Paljudel juhtudel pole selgeid eristustunnuseid, nt sõnavariandid kartul ja tuhl(is), kapsas ja kaapsas, reetkamm ja reigam(m). Kindlate häälikuliste kriteeriumide puudumisel võib variantide murdelevik anda väärtuslikku teavet võimalike laenuallikate kohta. Rühma murretes esinevate süstikut märkivate etümoloogiliselt seotud laensõnade ja nende kohalike edasiarenduste analüüs illustreerib sõnavarasuhete komplitseeritust eesti murretes.

Märksõnad: eesti murded, tüve varieerumine, alamsaksa laenud, saksa laenud, rootsi laenud, eestirootsi laenud, vene laenud, läti laenud 